\title{
O passado de uma ilusão e o futuro de uma tragédia
}

\author{
The past of an illusion and the future of a tragedy
}

\section{Renato dos Santos ; Diego Luiz Warmling*}

Resumo: Dos desdobramentos freudianos acerca da civilização, questionaremos como, diante da eminencia de um futuro trágico, a indagação de formas alternativas de gozo pode originar uma sociedade menos hostil. Partindo de noções como pulsão de morte, agressividade e Super-Eu, veremos que a racionalização dos afetos não reclama nossa destrutividade. Da antinomia entre Eros e Thanatos, Freud conclama a independência das pulsões agressivas, alegando que a civilização é vivenciada como mal-estar. Assinalando como os desejos do outro estão implicados nos nossos, acentuaremos que a agressividade instaura o Super-Eu, cuja função é impor sobre o Eu a mesma hostilidade que este satisfaria nos outros. Exercendo autoridade interna, o Super-Eu atravessa a subjetividade, indicando que não há nada que não garanta nossa própria catástrofe. Mas se a civilização está edificada sobre o resto da liberdade individual, então talvez a responsabilização pelo desejo permita pensar novas formas de subjetivação e, quiçá, numa sociedade menos hostil.

Palavras-chave: Psicanálise; Pulsão de morte; Cultura; Entropia

Abstract: From the Freudian developments about civilization, we will question how, in view of the imminence of a tragic future, the question of alternative forms of enjoyment can originate a less hostile society. Starting from notions such as death drive, aggressiveness and Super-Self, we will see that the rationalization of affections does not claim our destructiveness. From the antinomy between Eros and Thanatos, Freud calls for the independence of aggressive drives, understanding that civilization is experienced as malaise. Pointing out how the other's desires are implicated in ours, we will see that aggressiveness establishes the Super-Self, whose function is to impose on the Self the same hostility that the latter would wish to satisfy on others. Exercising internal authority, the Super-Self goes through subjectivity, indicating that there is nothing that does not guarantee our own catastrophe. But if civilization is built on the rest of individual freedom, then perhaps accountability for desire will allow us to think about new forms of subjectivity and, perhaps, in a less hostile society.

Keywords: Psychoanalysis; Death instinct; Culture; Entropy

Doutorando em Filosofia pela Pontifícia Universidade Católica renatodossantos1@hotmail.com ORCID: https://orcid.org/0000-0002-1402-7162

** Doutorando em Filosofia na Universidade Federal de Santa

Catarina, Florianópolis, SC. E-mail: diegowarmling@hotmail.com ORCID: https://orcid.org/0000-0003-4400-8170 


\section{1) Agressividade, inibição e a impossibilidade da racionalização dos afetos}

$\mathrm{Na}$ intenção de aplacar os sofrimentos e injustiças reincidentes sobre o indivíduo, a civilização busca estabelecer vínculos como os laços afetivos e amorosos, cujas funções residem em desviar a libido de suas metas sexuais. De fato, se, no ápice de uma relação, os amantes se bastam, em nenhum outro caso Eros se revela tão claramente. O amor "não admite ir além”. Mas é sob a pressão causada pelas decepções afetivas que os neuróticos padecem. Portanto, o tal estado de afeto onde dois amantes nada necessitam além de si próprios, não existe factualmente.

Posto que as dificuldades da evolução cultural são concomitantes aos empecilhos enfrentados pelo indivíduo em seu desenvolvimento, a civilização não só não se contenta com a união entre dois seres, como mobiliza quantias consideráveis de forças para condicionar a vida sexual. A função do trabalho psicanalítico reside em tornar claro o quanto estas instâncias mobilizam "em grau máximo libido inibida na meta, para fortalecer os vínculos comunitários através de relações de amizade"2. Estes são os casos, por exemplo, de exigências sociais como as dos mandamentos "ama o próximo como a ti mesmo" ou "ama teus inimigos".

A sociedade sempre se pautou num ideal de civilização em que a virtude é o bem mais desejável. No Seminário VII, que versa sobre a ética da psicanálise, Lacan critica a ética proposta por Aristóteles, conforme estabelecida na Ética a Nicômaco. Para ele ${ }^{3}$, a ética aristotélica "é uma ética do caráter. Formação do caráter, dinâmica dos hábitos ainda mais, ação em vista dos hábitos, do adestramento, da educação”. A racionalização das paixões, dos comportamentos, foi o grande objetivo que norteou o estagirita. De fato, tratava-se aí de um adestramento, pois se "a virtude moral ou ética é o produto do hábito"4, este hábito refere-se ao condicionamento dos indivíduos por parte da moralidade da sociedade.

A respeito dos dois mandamentos supracitados, a fim de remediar as manifestações de agressividade que jazem em nós, diz-se que, em favor da civilização, são impostas as exigências de amar ao outro como a si mesmo e de amar, inclusive, os nossos inimigos. Todavia, há de se perguntar em qual medida estas imposições nos ajudariam enquanto considerarmos que o amor é algo precioso, do qual não podemos nos despender

\footnotetext{
${ }^{1}$ FREUD, O Mal-Estar na Civilização, p. 72

${ }^{2}$ FREUD, O Mal-Estar na Civilização, p. 72

${ }^{3}$ Idem, p. 22

4 "Sendo a virtude de dois tipos, nomeadamente, intelectual e moral, deve-se a produção e ampliação da primeira, sobretudo à instrução, exigindo isso consequentemente experiência e tempo. A virtude moral ou ética é o produto do hábito, sendo seu nome derivado, com uma ligeira variação, dessa palavra. E, portanto, fica evidente, inclusive, que não é a natureza que produz nenhuma das virtudes morais em nós, uma vez que nada que seja natural é passível de ser alterado pelo hábito” (Cf. ARISTÓTELES, Ética a Nicômaco, p. 81).
} 
irresponsavelmente. Em verdade, quem de algum modo ama outrem, impõe-se deveres que só serão cumpridos mediante sacrifícios, pois, para o eu, outrem faz por merecer o seu amor. E se sob muitos aspectos o outro se assemelha a mim, de modo que encontro nele um espelho de mim mesmo. Não raro ele é, ademais, "tão mais perfeito do que eu que posso amar nele o meu ideal de mim" ${ }^{5}$. Na contramão de tais mandamentos, dizemos então que, na prática, o amor é um bem estimado; um privilégio que o indivíduo dedica aos seus entes queridos, sendo injusto, portanto, igualá-los a algum desconhecido.

Seguindo o enlace de $O$ Mal-Estar na Civilização, diferentemente de quem amo, este tal desconhecido não só não é digno de meu amor, como está muito mais propenso à minha hostilidade. Sinto-me mais inclinado a desprezá-lo do que amá-lo. E se, na via inversa, também lhe solicitam que me ame tanto quanto ama a si, é provável que sua resposta não seja muito diferente do que seria a minha. Meus desconhecidos me rejeitam pelos mesmos motivos que eu os rejeitou. Para Freud, isto permite a seguinte conclusão: enquanto estas diferenças não forem suplantadas, obedecer exigências éticas assim elevadas implicará em "danos aos propósitos da cultura, por estabelecer prêmios para a maldade"6.

O que tais mandamentos tendem a negar quando proclamam seus imperativos é o fato do homem não ser uma criatura branda, passiva e avida de amor. Adotando uma rejeição voluntária de nosso caráter hostil, deixam de incluir, entre nossos dotes, um forte quinhão de agressividade. Por mais vantajosos que sejam junto a civilização, quando incidem sobre os indivíduos, tais imperativos tendem a se tornar um peso bastante extremo e irracional; e isto vale inclusive para quem compreende quão necessários são os vínculos cooperativos à garantia do bem-estar.

Sem abdicar desta nossa cota de crueldade, a psicanálise reclama o reconhecimento de que, para o sujeito, o outro não é somente um colaborador sexual, mas um objeto capaz de satisfazer suas tentações mais cruéis. O homem, diz Freud (2010, p. 77), "é o lobo do homem". Contudo, se entendemos que, ao admitir nossa natureza agressiva, faz-se necessário o uso de métodos restritivos à sexualidade (pulsão inibida na meta), então no que tange os modos como a cultura incide sobre os indivíduos, somos obrigados tornar claras algumas diferenças entre O Futuro de uma Ilusão (1927) e as considerações tecidas em O Mal-Estar na Civilização (1930).

Em 1927, predominava a ideia de que, por meio de racionalizações, conseguiríamos aprender a aceitar as exigências impostas socialmente. Neste escopo, é plausível dizer que Freud apoiava-se numa concepção esperançosa dos vínculos sociais, acreditando assim numa possível reconciliação do sujeito com a civilização. Galgando uma visão progressista das circunstâncias, esperava-se que fossemos capazes de renovar nossas próprias

\footnotetext{
${ }^{5}$ FREUD, O Mal-Estar na Civilização, p. 74

${ }^{6}$ FREUD, O Mal-Estar na Civilização, p. 76
} 
exigências, de modo que chegaria o momento onde poder-se-ia pensar na extinção das proibições externas, que, desde as instâncias mais egóicas, causam prejuízos à coesão social. Todavia, uma visão assim tão otimista tende a passar por alto um exame mais detalhado desta nossa natureza cruel, agressiva, prazerosa e, num só tempo, constituinte das relações afetivas e sociais.

O Futuro de uma Ilusão passou por alto não somente o fato da agressividade resistir às regulações impostas pelo mundo externo (proibições e exigências), mas que ela é responsável por efetivar os mais distintos laços de cooperação. A respeito da agressividade, pensava-se que "se tratava simplesmente de uma forma de conduta que os seres humanos mantinham ou rejeitavam segundo lhes era ou não conveniente"7. Diferentemente da concepção de 1930, Freud não menciona a crueldade humana nem como fonte de exigências incidentes sobre o indivíduo, nem como obstáculo para uma possível reconciliação com a civilização.

Este progressismo parece estar encrustado naquilo que, anos antes, Freud já havia rechaçado sobre a teoria das pulsões: a ideia de que as motivações egóicas e altruístas representavam, respectivamente, as pulsões de autoconservação e sexuais, que, por si só, garantiriam a impossibilidade das demandas sociais se imporem sobre os interesses do indivíduo. O que "O Mal-Estar..."(1930) torna a considerar são os deslocamentos teóricos de 1920, quando dualismo pulsional é reafirmado, e se concebe a independência de uma pulsão agressiva ou destrutiva.

Considerando o aspecto prático ${ }^{8}$ daquilo que a todo instante tende a reconduzir os seres vivos ao estado anorgânico, é a análise desta variante pulsional que constituirá o eixo d'O Mal-Estar na Civilização. Segundo Garcia-Roza, é aqui onde Freud afirma a autonomia da pulsão de morte, agora sob o signo da destruição: "destrutividade e sexualidade passam a ser consideradas com inteira autonomia uma com respeito à outra" " É o reconhecimento deste aspecto agressivo de nossa conduta quem proporcionou uma mudança na teoria das pulsões, pois não se trata mais da pulsão de dominação conforme os moldes infantis (indiferença sobre o sofrimento alheio), mas de uma pulsão destrutiva que ocupa todos os âmbitos do comportamento e "vai se exprimir tanto através de condutas sociais banais [...], como através de condutas consideradas como associais" ${ }^{10}$.

\footnotetext{
${ }^{7}$ DEIGH, La Ultima Teoría da la Civilización de Freud, p. 351

${ }^{8}$ Introduzida no escopo de um registro especulativo de Para Além do Princípio do Prazer, a pulsão de destruição vem caracterizar aquilo que nas pulsões de morte produz efeitos e se faz reconhecer na experiência. De modo a assinalar os objetivos das pulsões de morte dentro de uma perspectiva factual (biologia e psicologia), tal qual a pulsão de agressão, a pulsão de destruição surge em 1920 a fim de qualificar “as pulsões de morte enquanto voltadas para o exterior. [...] a destruição do objeto" (LAPLANCHE; PONTALIS, Vocabulário da psicanálise, p. 510), o que poderia explicar o abando daquele otimismo de $O$ Futuro de Uma Ilusão.

${ }^{9}$ GARCIA-ROZA, Introdução à metapsicologia freudiana, p. 159

${ }^{10}$ ENRIQUEZ, Da Horda ao Estado, p. 108
} 
Balizados pelos capítulos V e VI, trata-se de pôr em questão a natureza do nosso "mal-estar" por meio da dualidade pulsional reivindicada dez anos antes, no âmbito de Além do Princípio do Prazer: "ao lado de Eros, um instinto de morte"11. Para além dos aspectos conservadores e repetitivos das pulsões, Freud vislumbrou a existência de uma tendência que visa conduzir-nos à vida anorgânica. Contudo, se as manifestações de Eros se faziam bastante evidentes, a força de Thanatos (pulsão de morte) era, pelo contrário, silenciosa e tácita:

Não era fácil mostrar a atividade desse suposto instinto de morte. As manifestações de Eros eram suficientemente visíveis e ruidosas; era de supor que o instinto de morte trabalhasse silenciosamente. [...] Levava-nos mais longe a ideia de que uma parte do instinto se volta contra o mundo externo e depois vem à luz como instinto de agressão e destruição. Assim o instinto seria obrigado ao serviço de Eros, na medida em que o vivente destruiria outras coisas, animadas e inanimadas, em vez de si próprio ${ }^{12}$

Ora, e se assim percebemos que todas as formas de violência são representadas por Freud numa única e mesma pulsão, é a constatação desta nossa tendência agressiva que revela-nos a besta selvagem que somos. Excetuando quem amamos, não poupamos nem a nossa espécie; exploramos os nossos semelhantes sem atentar para as circunstâncias. Mas é justamente aqui, ou seja, sobre esta perturbada relação com outrem, que as instâncias civilizatórias se instalam, pois os interesses racionais não se bastam. Impondo-nos sérios dispêndios, "a civilização tem de recorrer a tudo para pôr limites aos instintos agressivos do homem"13.

A fim de que possa manter sob seu controle a destrutividade humana, não raro se vale de imperativos morais que, em verdade, opilam-nos de exigências, mas cujas demandas jamais serão totalmente cumpridas, mesmo quando razoavelmente aceitas. Constantemente ameaçada de desintegração, precisa promover laços de afeto entre seus membros para não padecer. Favorecendo métodos restritivos que cooptam as pessoas à manterem relações inibidas em suas metas, se vê obrigada a promover entre os homens um sentimento generalizado de fato, que implica "forçosamente a formulação de demandas excessivas no autocontrole e na boa vontade de todos os seres"14. Buscando prevenir, controlar e inibir os excessos mais acentuados de violência, espera punir e direcionar os infratores por meio de leis e direitos. Face à inerência desta hostil natureza humana, a marcha da civilização nada mais é do que a marcha contrária à natureza humana agressiva.

Os discursos morais acreditaram que, com a postulação de regras e mandamentos, seria possível fazer com que as pulsões mortíferas que atravessam nossa conduta fossem

\footnotetext{
${ }^{11}$ FREUD, O Mal-Estar na Civilização, p. 86

${ }^{12}$ FREUD, O Mal-Estar na Civilização, p. 86

${ }^{13}$ FREUD, O Mal-Estar na Civilização, p. 78

${ }^{14}$ DEIGH, ,La Ultima Teoría da la Civilización de Freud, p. 349
} 
controladas. A pulsão de morte estaria, assim, socialmente erradicada. Para Lacan, Aristóteles é claro em classificar um grande número de desejos - que, para a psicanálise, são ordem sexual - sob a "dimensão das anomalias monstruosas - bestialidade é o termo que ele utiliza a respeito deles" ${ }^{15}$.

Todavia, considerando que, para Freud, os afetos jamais deixam de ser sexuais, se reafirmamos o dualismo pulsional dentro do âmbito da cultura e se, em consequência disto, entendemos também que há um limite para toda boa vontade e autocontrole dos homens, então não demora para compreendermos como, para além dos vínculos amorosos, impera a influência de um fator adicional, cujos pressupostos têm a ver com nossa natureza eminentemente agressiva.

E é isto o que traz às claras a seguinte conclusão: mesmo com seus dispositivos em plena função, não há como negar que todos os empenhos civilizacionais não foram muito além de seus respectivos pontos de partida. Em função deste pendor agressivo, o interesse que a comunidade tem sobre o trabalho não se basta para manter sua coesão, pois as paixões são muito mais poderosas do que qualquer interesse racional, na contramão, portanto, do que sonhou Aristóteles e tantos outros teóricos que se apoiaram no uso da razão para frear nossos impulsos. Suas leis e restrições estão, em verdade, distantes de compreender e expressar as sutis e tênues agressividades humanas. E se à esta altura nos damos conta de que a possibilidade de uma universalização do amor pela via civilizacional não se basta frente aos nossos pendores destrutivos, também não demora para percebermos que a marcha comunista tampouco encontrou alguma fórmula definitiva para a extinção do mal.

Para este movimento, enquanto o homem é inequivocamente bom, é a propriedade privada quem lhe perverte a natureza. Em um ato de rebeldia dos oprimidos contra aos opressores autoproclamados, toda a maldade entre os homens só desvanecerá se "a propriedade privada for abolida, todos os bens forem tornados comuns e todos os homens puderem desfrutá-los”16. Todavia, de um ponto de vista psicológico, estes índices teóricos são irreais, pois, ainda que possamos subtrair do homem sua propensão agressiva mediante uma disposição à mutua comunhão, nada mudamos a respeito da natureza da agressividade ou da influência que esta possui sobre nosso comportamento, quando usa ou abusa de seus poderes para atingir seus propósitos. Tais movimentos se equivocam quando acreditam que a abolição da ideia de propriedade seria suficiente para extinguir a má vontade; "pelo contrário, ela utiliza a agressão para reforçar a coesão do grupo, permitindo-lhe tratar os estrangeiros como inimigos que podem ser desprezados e destruídos" ${ }^{17}$.

\footnotetext{
${ }^{15}$ LACAN, O seminário, livro 7: a ética da psicanálise, p. 16

${ }^{16}$ FREUD, O Mal-Estar na Civilização, p. 79

${ }^{17}$ ENRIQUEZ, Da Horda ao Estado, p. 109
} 
Para Freud, a agressividade não surge com o advento da propriedade, mas é o traço humano mais fundamental. A agressividade é um resquício vivo e indelével de nossa constituição, e que nos acompanha por onde quer que vamos, sendo, assim, "o sedimento de toda relação terna e amorosa entre as pessoas" ${ }^{18}$. Em vistas de sua manutenção, adota uma estratégia dupla: se de um lado impede-nos de expressar a agressividade entre aqueles de nosso grupo, é favorecendo vínculos libidinais de mútua identificação que torna inimigos quem lhes é diferente, quer representem ameaças reais ou não. À revelia daquilo que seria uma universalização dos laços afetivos, Freud diz que só é possível reunir um número grande e coeso de pessoas pela via do amor enquanto entre nelas resistir a possibilidade de se exteriorizar a agressividade, as zombarias, as perversidades, etc. - não à toa, continua, "que a tentativa de instaurar na Rússia uma nova civilização comunista encontre seu apoio psicológico na perseguição à burguesia” ${ }^{19}$.

Desta feita, se uma vez atinamos para esta impossibilidade de fomentarmos os vínculos sociais fora do montante de agressividade que resiste entre os indivíduos, compreendemos enfim o motivo de não sermos realmente felizes em meio à civilização. Se um grupo jamais pode viver totalmente em guerra, então também precisa de repouso, mas, paradoxalmente, é aí (nos períodos de paz) onde se vê obrigado a estabelecer "as restrições à sexualidade e à agressividade, que afetarão seus membros de maneira particularmente aguda" ${ }^{20}$. Assim, quando comparados aos homens primitivos ${ }^{21}$, parece que trocamos nossa cota de felicidade por uma parcela irrisória de segurança. Se por um lado a cultura nos impôs sacrifícios à vida sexual, do outro, é nossa propensão agressiva que foi mediada.

Reconhecendo o quanto a elucidação de uma teoria das pulsões foi truculenta para o desenvolvimento de sua obra ${ }^{22}$, ao dar voz à esta nossa tendência destrutiva, Freud não só

\footnotetext{
${ }^{18}$ FREUD, O Mal-Estar na Civilização, p. 80

${ }^{19}$ FREUD, O Mal-Estar na Civilização, p. 81-82

${ }^{20}$ ENRIQUEZ, Da Horda ao Estado, p. 110

${ }^{21}$ Em verdade, não podemos negar que o homem primitivo esteva realmente em melhores condições de satisfazer seus instintos e pulsões, mas isso tão somente enquanto os ventos da fortuna não abalassem sua segurança. E não esqueçamos que, nesta sociedade primitiva, apenas o chefe gozava de sua liberdade; os demais viviam sob plena submissão.

${ }^{22}$ Ao longo sexto capítulo d'O Mal-Estar na Civilização, Freud reconhece suas dificuldades entorno da teoria das pulsões e se empenha em resumir alguns dos pressupostos norteadores que o conduziram até aqui quando assume a autonomia da pulsão de destruição. Com efeito, acerca da primeira enunciação de sua teoria pulsional, diz que, em favor da manutenção da espécie, “a fome poderia representar os instintos que querem manter o ser individual, enquanto o amor procura pelos objetos" (FREUD, O Mal-Estar na Civilização, p. 84); donde se segue a introdução do conceito de libido e a respectiva distinção entre libido do Eu e libido dirigida ao objeto. Mas, se a neurose vinha às claras tão somente no embate entre os interesses de autopreservação e as exigências libidinais externas, então foi imprescindível introduzir uma mudança de acentuação. Da dupla compreensão de que o Eu achava-se originalmente investido de libido e de que, mesmo dirigindo-se aos objetos, esta libido poderia tornar ao eu e transformar-se em libido narcísica, "o conceito de narcisismo tornou possível apreender analiticamente a neurose traumática, assim como a psicose e muitas afecções vizinhas a esta” (FREUD, O Mal-Estar na Civilização, p. 85). Contudo, faltava ainda a elucidação de
} 
fornece novas armas às forças interditantes da cultura, como defende que é justamente por causa da presença onisciente desta pulsão que não podemos deixar de reconhecer "um prazer narcísico extraordinariamente elevado" ${ }^{23}$. A pulsão de destruição é o próprio real em "carne e osso", uma vez que "mostra ao Eu a realização de seus antigos desejos de onipotência”" Diante dela, o outro só existe como instrumento de satisfação, cujos fins são testemunhos de como os desejos infantis mais arcaicos podem vir à tona na realidade.

Quando moderada em sua meta, pode, em verdade, proporcionar a satisfação de nossas necessidades, assim como o mando sobre a natureza. Contudo, posto o desejo dos homens em se igualarem aos deuses, é por via destas características megalomaníacas que, sem jamais satisfazer-nos com o aviltamento de alguns poucos, desejamos a destruição de tudo e de todos. Desta forma, sem com isto nos depararmos com qualquer propósito sexual de autoconservação ${ }^{25}$, faz-se imperativa a interpretação segundo a qual este nosso pendor agressivo é, antes de mais nada, uma disposição pulsional autônoma e original que a todo instante se mostra como obstáculo à civilização; o que, de acordo com os postulados freudianos alocáveis na segunda tópica, nos revelaria a mais fundamental ligação entre as pulsões e os poderes celestes de criação, conservação e destruição. Estamos nos referindo à antiga batalha entre os poderes Eros e Thanatos ${ }^{26}$; luta esta que se traduz em cada um de nós como sendo a aceitação ou negação do outro por meio da aceitação ou rejeição das implicações que os desejos do outro possuem sobre os nossos próprios desejos.

\section{2) O Super-Eu e a internalização da culpa: a eminência de uma catástrofe}

Isto posto, resta compreender por que meios as instâncias civilizacionais controlam as manifestações agressivas e egóicas da pulsão de morte. O movimento de O Mal-Estar na Civilização assinala a maneira como a agressividade introjetada sobre o Eu se volta contra ele, de modo a produzir, pela via do Super-Eu, um sentimento de culpa. Com efeito, a

um passo seguinte, dado somente em 1920, e segundo o qual as pulsões jamais poderiam ser todas de uma mesma espécie. Com o advento de Para Além do Princípio do Prazer, emerge a ideia de que não seria possível passar por alto a hipótese de uma pulsão de morte fundamental às pulsões de vida, e cuja função seria dissolver as criações de Eros, devolvendo-as "ao estado primordial inorgânico" (FREUD, O Mal-Estar na Civilização, p. 86). Como já bem salientamos, o reclame deste aspecto hostil, destrutivo, violento e egóico de nossas condutas em meio à civilização constituirá o eixo central da obra de 1930.

${ }^{23}$ FREUD, O Mal-Estar na Civilização, p. 89

${ }^{24}$ FREUD, O Mal-Estar na Civilização, p. 89

${ }^{25}$ Tais como aqueles encontrados ao longo de toda a primeira tópica.

${ }^{26}$ Enquanto Eros, seguindo seu programa, pretende juntar libidinalmente os indivíduos isolados, do outro lado, é Thanatos quem, pela via deste nosso instinto destrutivo inato, nos põe contra a cultura e tonar evidente "a hostilidade de um contra todos e de todos contra um" (FREUD, O Mal-Estar na Civilização, p. 90). 
instauração de uma "consciência moral” através do Super-Eu manifesta sobre o Eu a mesma agressividade que este gostaria de direcionar aos outros.

A tensão gerada entre Eu e Super-Eu abre margem a um sentimento de culpa, que não só é resultado da angústia infantil diante da autoridade dos pais - "temendo não mais ser amada, a criança é levada a renunciar a satisfazer as pulsões, guiadas unicamente pela busca do prazer" 27 -, como, quando as formas da arbitrariedade parental são orientadas ao Super-Eu, sua origem torna-se interna, não sendo "possível mascarar do Super-Eu aquilo que persiste no eu do desejo de satisfazer a pulsão" ${ }^{28}$. Desta feita, se a civilização tende a vigiar e controlar o impulso destrutivo dos homens por intermédio de uma instância reguladora interna (o Super-Eu, que opera sobre o Eu como um governante cujos poderes recaem sobre uma comunidade conquistada), questionaremos enfim o modo como o sentimento de culpa gerado pela cultura vive sob nossas condutas, sendo vivenciado como mal-estar.

Em verdade, quando comparado aos outros animais e a ele mesmo em sua vida primitiva, dizemos, sobre o humano civilizado, tanto que não é capaz de encontrar seu quinhão de felicidade em sociedades como as das formigas e abelhas, como que, no mundo primitivo, um eventual avanço da libido pode ter desencadeado uma "renovada oposição do instinto de destruição" ${ }^{29}$. Se desde Além do Princípio do Prazer compreendemos que, dada sua impossibilidade de manifestar-se completamente, a pulsão de morte se alia ora a Eros, ora à pulsão de destruição, o que Freud empenha-se em fazer à esta altura de O Mal-Estar na Civilização é opor as forças conjuntivas de Eros - cuja função é combinar os indivíduos $^{30}$ entre si -, ao poder dissolvente de Thanatos, representante da hostilidade vigente em cada um de nós e opositor do programa civilizacional.

O panorama da civilização será, portanto, a consequência deste conflito. Entretanto, há de questionar por quais meios a cultura busca mediar a destrutividade que a afronta? Segundo Freud, se é característico de nossa sociedade não sermos felizes em outras formações comunitárias, logo nos salta a ideia de que grande parte da hostilidade internalizada pelo sujeito a partir das instituições culturais torna a ser dirigida contra o $\mathrm{Eu}$, sendo acolhida por uma parte dele que nada mais é do que a sua contraposição. Estamos falando do Super-Eu; domínio este que, "como 'consciência', dispõe-se a exercer contra o Eu a mesma severa agressividade que o Eu gostaria de satisfazer em outros indivíduos"31.

Como já bem apontamos, da tensão criada entre o rigor do Super-eu e os impulsos do Eu, emerge a consciência de culpa, que submete o sujeito aos mandos e desmandos de

\footnotetext{
${ }^{27}$ ROUDINESCO; PLON, Dicionário de psicanálise, p. 492

${ }^{28}$ Idem, ibidem

${ }^{29}$ FREUD, O Mal-Estar na Civilização, p. 91

${ }^{30} \mathrm{E}$ também famílias, raças, povos e nações.

${ }^{31}$ FREUD, O Mal-Estar na Civilização, p. 92
} 
uma vontade já internalizada e se torna manifesta na necessidade de punição. Através da introjeção de leis que, por si só, tendem a mediar os possíveis prazeres de pulsão de destruição, a civilização recai sobre indivíduo como se fosse enfraquecê-lo, vigiando-o desde seu interior. E mesmo que, sob muitas variantes, o sujeito reconheça em si a intenção de executar algum mal (sem necessariamente ir às vias de fato), a cultura agirá de tal forma que o levará a se questionar se a simples proposição de uma hostilidade não se equipara à sua execução factual. Seja indo às vias de fato, seja intencionando, a todo momento pressupõe-se o reconhecimento do "mal como algo repreensível, cuja execução deve ser evitada" 32 ; o que abre espaço à seguinte distinção: o mal enquanto algo externo causado principalmente pela angústia diante da recusa do amor - e o mal como algo concomitante à internalização das regras externas no Super-Eu.

Ora, sendo-nos impossível distinguir de imediato as ações boas e más, não raro o mal é tido, pelo indivíduo, como um objeto de prazer e desejo, destituído de qualquer periculosidade. Contudo, é em razão da impossibilidade de manifestarmos toda a nossa agressividade diante das influências alheias que se faz evidente o quanto somos submissos aos outros. Considerando que a irrestrita satisfação dos impulsos prazerosos se basta apenas mediante um estado ideal de coisas, deve haver um motivo pelo qual os homens se rendem às influências externas; e será esta dependência que nos mostrará o que, em primeira instância, pode ser considerado bom ou mau.

De acordo com Freud, a explicação mais aceitável para tal submissão é o medo que, desde a infância, temos de perder o amor de quem amamos. Quando crianças, tememos os castigos e as privações do amor daqueles que investimos de onipotência; razão pela qual respeitamos suas ordens e proibições. Se n'algum momento o perdemos o amor de quem dependemos, expomo-nos "ao perigo de que esse alguém tão poderoso demonstre a superioridade em forma de castigo" 33 . Neste sentido, o mal seria a manifestação daquilo que ameaça com a perda do amor.

Ora, mas vale ressaltar que este perigo só surge quando não conseguimos mais evitar de ser descobertos por quem amamos. Tal estado poderia ser compreendido como um estágio de "má consciência”, mas sua realidade mostra que esta "consciência de culpa não passa [...] de medo da perda do amor" ${ }^{34}$. Assim, se logo percebemos que tal angústia é um medo social, também não tarda para notarmos que ocorre uma grande mudança quando sua força é internalizada e se estabelece como um imperativo, do qual não conseguimos desviar-nos. Estamos falando do medo do Eu frente ao Super-Eu, que, uma vez instaurado, interiorizará a agressividade numa parte do ego, como "uma guarnição numa cidade conquistada” ${ }^{35}$.

\footnotetext{
${ }^{32}$ FREUD, O Mal-Estar na Civilização, p. 93

${ }^{33}$ FREUD, O Mal-Estar na Civilização, 94

${ }^{34}$ FREUD, O Mal-Estar na Civilização, p. 94

${ }^{35}$ FREUD, O Mal-Estar na Civilização, p. 92
} 
A internalização da culpa concomitante ao advento do Super-eu abre margem ao entendimento de que só num segundo estágio perder-se-ia falar em consciência ou arrependimento. Distintamente daquele estágio onde o medo possuía relação com os perigos de se perder o amor do objeto amado, o sentimento de culpa não só faz desaparece o medo de sermos descobertos, como diz que, diante da imperatividade do Super-Eu, até os nossos pensamentos mais escusos não conseguem ser acobertados.

O super-eu "atormenta o Eu pecador com as mesmas sensações de angústia e fica à espreita de oportunidades para fazê-lo ser punido pelo mundo exterior" ${ }^{36}$. E é por ser herdeiro daquela agressividade vigente desde as ameaças externas, que o Super-Eu "vai retorná-la contra o ego, comportando-se severa e cruelmente" ${ }^{37}$. Desta feita, se não há, para o eu, nada que possa esconder, então não tarda para a consciência moral evidenciar dois causos peculiares, relacionados com a ação da culpa sobre os indivíduos.

Com efeito, a começar pela estruturação do Ser moral, dizemos que quanto mais virtuoso for o indivíduo, tão mais rigorosa, severa e desconfiada será sua conduta em relação à si e aos outros, pois a ação do Super-eu lhe é mais severa e onipresente. Aumentando cada vez mais o poder de sua autoridade, o Super-Eu age sobre o Eu como se conhecesse até mesmo os seus desejos proibidos. Quando o sujeito se diz pecador, o faz em vistas de uma recusa da possibilidade de satisfazer seus impulsos, o que ocasiona um estado contínuo de frustração que só faz crescer as tentações.

E se entendemos que o desejo persiste à revelia de qualquer renúncia pulsional e que esta renúncia vem acompanhada do sentimento de culpa, então um outro causo aponta à acentuada promoção da consciência no Super-Eu a partir de infortúnios externos: enquanto as coisas forem brandas, a pessoa tende a agir parcimoniosamente, mas quando um infortúnio a atinge, ela castiga-se com privações e penitências. Recorrendo enfim à ideia de uma contínua aderência do Eu aos estágios infantis da consciência, Freud explica que, mesmo após a internalização das regras no Super-eu, em ambos os casos esta aderência subsiste de tal modo que a supremacia do destino passa a atuar como representante das instâncias parentais mais próximas: se o indivíduo se vê ameaçado de perder o amor, "inclina-se novamente ante a representação dos pais no Super-eu, que no momento da fortuna tendia a negligenciar" 38 .

Desta feita, o que se delineia a partir destas distinções e exemplos é a necessidade de reconhecermos a origem dupla do sentimento de culpa: num primeiro momento, o medo da autoridade alheia que obriga-nos "a renunciar a satisfações instintuais" ${ }^{9}$, logo adiante, o medo de infringir as regras diante onipresença do Super-Eu, que nos leva "ao

\footnotetext{
${ }^{36}$ FREUD, O Mal-Estar na Civilização, 95

${ }^{37}$ ENRIQUEZ, Da Horda ao Estado, p. 114

${ }^{38}$ FREUD, O Mal-Estar na Civilização, p. 97

${ }^{39}$ FREUD, O Mal-Estar na Civilização, p. 97
} 
castigo, dado que não se pode ocultar ao Super-Eu a continuação dos desejos proibidos" ${ }^{40}$. Ora, se por um lado o medo da perda do amor dos pais é causa de uma renúncia que tende, concomitantemente, a se relacionar com a sensação de culpa, com a internalização das regras no Super-Eu, a renúncia pulsional por meio de ordens explicitas já não se basta.

Sem conseguirem se esconder da imperatividade do Super-Eu, para além de qualquer punição direta, neste segundo estágio os desejos são persistentes, mas sempre acompanhados de uma desvantajosa economia libidinal, a saber: um sentimento de culpa, que gera uma necessidade de punição derivada do próprio sujeito, e não de um poder externo. Se antes esperava-se uma punição direta, agora o medo de perder o amor do objeto amado se torna permanente e se manifesta numa consciência interna de culpa. Portanto, a sequência para a internalização das regras no Super-Eu é a seguinte:

Primeiro, renúncia instintual devido ao medo à agressão da autoridade externa depois, estabelecimento da autoridade interna, renúncia instintual devido ao medo a ela, medo da consciência. No segundo caso, equiparação de ato mau e má intenção, e daí consciência de culpa, necessidade de castigo. A agressividade da consciência conserva a da autoridade ${ }^{41}$.

Não obstante, se até aqui as coisas parecem claras, é quando questiona o papel das renúncias impostas pelo mundo que Freud tece seus apontamentos mais psicanalíticos. Se de início a consciência surge como causa de uma abdicação de parcela de toda a satisfação pulsional, n'outro momento poderíamos defender uma tese bastante paradoxal: "a consciência é resultado da renúncia instintual, ou de que esta (a nós imposta do exterior) cria a consciência, que então exige mais renúncia instintual" ${ }^{42}$. De fato, tomando como exemplo o dinamismo dos efeitos da renúncia da pulsão de destruição sobre a consciência, vemos como, diante da impossibilidade de satisfação plena de nossa agressividade, esta é de tal forma acolhida pelo Super-Eu que, em verdade, aumenta seus efeitos sobe o Eu.

Contra a autoridade daqueles que nos são mais próximos, uma soma considerável de hostilidade pode ter se desenvolvido em nós desde a infância, mas - em vista do bem-estar comum - fomos obrigados a abdicar de partes bastante significativas desta agressividade. Conforme crescemos, encontramos saídas para situações econômicas assim difíceis ao acolhermos dentro de nós a autoridade do Super-Eu, que, por identificação, toma conta de toda a agressividade que, desde a tenra idade, gostaríamos de exercer sobre o outro.

Já na infância, carregamos uma polifonia de sentimentos ambivalentes: amamos nosso pai, mas também não conseguimos deixar de odiá-lo, pois é sua presença que impõe as primeiras limitações. A fim de nos livramos desta embaraçosa situação, nada resta senão identificarmo-nos com a imagem deste ser que nos impõe restrições. Assim, se

\footnotetext{
${ }^{40}$ FREUD, O Mal-Estar na Civilização, p. 97

${ }^{41}$ FREUD, O Mal-Estar na Civilização, p. 98

${ }^{42}$ FREUD, O Mal-Estar na Civilização, p. 99
} 
inicialmente o Eu infantil se vê obrigado a contentar-se com a frágil autoridade do pai e, paralelamente, vê-se também na necessidade de incorporar parte de suas imposições, então a "relação entre Super-Eu e Eu é o retorno, deformado pelo desejo, de relações reais entre o Eu ainda não dividido e um objeto externo"43.

Seguindo O Mal-Estar na Civilização, vemos como a incorporação da severidade externa no Super-eu possui menos relação com a autoridade que esperamos de sua parte, do que é herdeira das consequências de nossa hostilidade para com ela. Complementares, Freud diz que estas duas concepções acerca do Super-Eu possibilitam aceitar não só que a consciência é causa das renuncias pulsionais impostas pelo pai, mas que, num instante seguinte, será a renúncia de uma possível satisfação agressiva contra o mesmo quem tonificará as demandas da consciência, de modo a reforçar a crueldade do Super-eu. E se tornamos concomitantes os desenvolvimentos dos indivíduos e da humanidade, salta aos olhos como esta complementaridade se torna ainda mais evidente na medida que os membros da comunidade matam seu chefe (o pai onipotente) pelo fato deste não admitir em seus "filhos" uma sexualidade latente. Logo após o ódio ser satisfeito em forma de agressão, a comunidade é tomada pelo arrependimento e, do amor que daí decorre, instituem o Super-Eu por identificação com a imagem do pai:

Esse arrependimento era resultado da primordial ambivalência afetiva perante o pai, os filhos o odiavam, mas também o amavam. Depois que o ódio se satisfez com a agressão, veio à frente o amor, no arrependimento pelo ato, e instituiu o Super-eu por identificação com o pai, deu-lhe o poder do pai, como que por castigo pelo ato de agressão contra ele cometido, criou as restrições que deveriam impedir uma repetição do ato. E como o pendor agressivo contra o pai se repetiu nas gerações seguintes, também o sentimento de culpa persistiu e fortaleceu-se de novo com cada agressão suprimida e transferida para o Super-eu ${ }^{44}$.

Isto posto, pautado pelo propósito de reconhecer no sentimento de culpa o mais grave problema da evolução cultural e, com isto, mostrar que o preço a se pagar pelo progresso é a perda de parte de nossa felicidade, é com base n'algumas constatações sobre as neuroses que Freud empenha-se em tecer relações entre a consciência e o sentimento de culpa. Para ele, este tal sentimento nada é senão uma nuance da própria angustia, que, tácita sob todos os sintomas ${ }^{45}$, coincide com o medo ante o Super-Eu; motivo pelo qual se torna fácil conceber que a consciência de culpa permaneça no inconsciente ou emerja conforme um mal. Todavia, se à esta altura pode haver certa frouxidão na maneira como

\footnotetext{
${ }^{43}$ FREUD, O Mal-Estar na Civilização, p. 100

${ }^{44}$ FREUD, O Mal-Estar na Civilização, p. 104

${ }^{45}$ Ou seja, "ora reivindica ruidosamente para si a consciência inteira, ora se oculta de modo tão perfeito" (FREUD, O Mal-Estar na Civilização, p. 108)
} 
intercambiamos vocábulos como $S u p e r-E u$, consciência, sentimento de culpa, castigo e arrependimento, não cairíamos em demasia se os esclarecêssemos.

De acordo com o austríaco, se o Super-Eu é uma "instância explorada por nós", a consciência, sendo um dos âmbitos do Super-Eu, vigia as intenções do Ego e exerce sobre ele uma função judicativa e censória. Já o sentimento de culpa, ou seja, "a dureza do SuperEu”, é a severa percepção, por parte do Eu, de estar sendo vigiado, o que, em decorrência do medo deste âmbito assim crítico, abre caminho para a necessidade subjacente de castigo, aqui entendida como sendo a "expressão instintual do Eu, que por influência do Super-eu sádico tornou-se masoquista” - e isto só é assim enquanto o arrependimento for uma reação do eu (acompanhada ou não de castigo) para um "caso de sentimento de culpa" ${ }^{46}$. Desta feita, sendo que, tal qual a consciência de culpa ${ }^{47}$ e o $S u p e r-E u, o$ arrependimento também demonstra sua existência antes mesmo da consciência moral, é com o estabelecimento de uma autoridade interna que o sentimento de culpa passa a ser consequência tanto de ofensas intencionadas quanto de agressões levadas a cabo.

Se antes o sentimento de culpa era concomitante ao arrependimento, agora "a diferença entre agressão intencionada e realizada perde sua força, devido à onisciência do Super-eu" ${ }^{48}$. Com o advento do Super-Eu, o sentimento de culpa compreende ambas as possibilidades como fontes distintas de agressão mas que, quando exercem efeito sobre o indivíduo, atuam sistematicamente conjuntas: enquanto a ação consumada é consciente, sua estrita proposição permanece inconsciente. Como verificou a trabalho psicanalítico, à medida que compreendemos o quanto as neuroses são satisfações de desejos recalcado, observa-se como nelas se faz latente um sentimento de culpa. Para Freud, isto nos permite inferir que "quando uma tendência instintual sucumbe à repressão, seus elementos libidinais se transformam em sintomas, seus componentes agressivos, em sentimento de culpa" ${ }^{49}$.

Assim, se, diante do amor gerado pela morte do pai, compreendemos que não é preciso irmos às vias de fato para nos sentirmos culpados por uma falta - pois este sentimento é antes a expressão da eterna ambivalência entre Eros e a pulsão de destruição ou morte -, é de causar espanto como Freud não só faz referência à "morte do pai” (complexo de édipo) ao tratar de tal sensação, como em tende a igualar as instâncias psicológicas individuais com o dinamismo da esfera coletiva.

Cada um pode representar para o outro alguma coisa da imagem do pai, [...] cada um pode desejar, por sua vez, ocupar a posição do pai. A agressividade

\footnotetext{
${ }^{46}$ Cf. FREUD, O Mal-Estar na Civilização, p. 109-110

${ }^{47}$ No que se compreende por consciência de culpa, vale ressaltar que esta é primordial ao tanto ao $S u p e r-E u$ quanto à consciência moral, pois é “a expressão imediata do medo à autoridade externa, o reconhecimento da tensão entre o Eu e esta última, o derivado” (FREUD, O Mal-Estar na Civilização, p. 110).

${ }^{48}$ FREUD, O Mal-Estar na Civilização, p. 110

${ }^{49}$ FREUD, O Mal-Estar na Civilização, p. 113
} 
voltada contra o pai pode então se dirigir contra todos os outros, da mesma forma que o amor endereçado ao pai deverá se endereçar a todos os outros. Para impedir esta possibilidade de violência generalizada de se realizar, a civilização deve reforçar o sentimento de culpa ${ }^{50}$.

Em verdade, a cultura se submete ao mesmo erotismo que outrora uniu em uma só massa os mais distintos homens; e alcançou seus fins apenas mediante a intensificação do sentimento de culpa: “o que teve início com o pai se completa na massa” ${ }^{51}$. É, portanto, a eterna luta entre Eros enquanto potência unificante/criadora e Thanatos como pulsão de morte ou destruição quem caracterizará o dinamismo que se desenvolve na humanidade, nos indivíduos e na própria vida orgânica. O progresso da civilização é a modificação que os processos vitais individuais vivenciam quando são impelidos por Eros e Ananke à se unirem com outros indivíduos.

Se a evolução da família à humanidade é decorrente da força de Eros e fornece, por assim dizer, combustível à pulsão de destruição, então "quanto mais a vida se manifesta, mais as unidades se constroem e, correlativamente, mais a pulsão de destruição encontra objetos para agredir" ${ }^{52}$. É como se o pertencimento à uma civilização dissolvesse as mais distintas diferenças e, do interior de uma massa coletiva, emergisse um sentimento de culpa capaz de perpassar todos os poros do social. Ambos os processos (individual e coletivo) são "de natureza muito parecida, se não forem o mesmo processo realizado em objetos diferentes" 53 .

Contudo, ainda que sejam grandes as afinidades entre a integração do indivíduo numa comunidade e a formação de um coletivo, não há como deixarmos de acentuar os traços que impossibilitam esta assimilação. Ora, enquanto que o indivíduo, na busca por seu quinhão de felicidade, segue o programa do princípio do prazer fomentado por Eros e, com isto, só aceita integrar-se à comunidade enquanto sua adaptação é condição para alcançar seus fins, a cultura está preocupada em "criar uma unidade a partir dos indivíduos humanos" 54 .

Em outros termos, na medida em que o progresso individual emerge como produto de aspirações egóicas a altruísticas, quando se trata da civilização, não podemos negar que a busca pela felicidade ainda subsiste, mas é relegada para o segundo plano; não à toa que Freud chega à seguinte asserção: "parece que a criação de uma grande comunidade humana teria êxito maior se não fosse preciso preocupar-se com a felicidade do indivíduo" ${ }^{55}$. E se, diante disto, em momento algum a cultura se vê preocupada com os

\footnotetext{
${ }^{50}$ ENRIQUEZ, Da Horda ao Estado, p. 115

${ }^{51}$ FREUD, O Mal-Estar na Civilização, p. 105

${ }^{52}$ ENRIQUEZ, Da Horda ao Estado, p. 115

${ }^{53}$ FREUD, O Mal-Estar na Civilização, p. 114

${ }^{54}$ FREUD, O Mal-Estar na Civilização, p. 115

${ }^{55}$ FREUD, O Mal-Estar na Civilização, p. 115
} 
indivíduos, então está mais facilmente em condições de realizar seu objetivo: a dissolução do sujeito na massa.

Relativamente a estas duas tendências, dizemos que sociedade e indivíduo tem de digladiar-se um contra o outro, a fim disputar entre si a posse do terreno. Mas é justamente aqui onde, ao admitir um equilíbrio final no indivíduo, Freud abre mão de uma última analogia, relacionada sobretudo com a possibilidade de inferirmos sobre o social a influência de um Super-Eu. Trata-se do Super-Eu Cultural, cuja condição de possibilidade é semelhante à do indivíduo, mas que se respalda nas impressões psíquicas deixadas pela ação de grandes líderes ou figuras históricas que, ultrajados em vida, são tornados deuses, ou seja, "da mesma forma que o superego individual é a consequência da tragédia que se encenou no círculo familiar" ${ }^{56}$.

Desta forma, se impera no interior de cada qual uma instância reguladora cujos fins remetem à uma mediação de nossos impulsos agressivos, é de se esperar que a mesma dinâmica se aplique ao interior de uma cultura, pois, assim como ocorre com o indivíduo, o Super-Eu Cultural institui exigências que, se não cumpridas, desembocam na consciência angustiada e que, por sua imperatividade, soam como éticas.

De fato, por tratar das relações dos indivíduos entre si, os códigos éticos se dedicam aos pontos mais frágeis da cultura, pois sobre eles recai a árdua tarefa de manter a coesão social frente ao pendor dos homens à agressão mutua. De mandamentos como aqueles citados anteriormente, a ética se apresenta a partir de sua imperatividade e pouco considera as demandas que os indivíduos são capazes de suportar.

Em decorrência de suas proibições e princípios, ela pouco atenta à felicidade do Eu, "não levando devidamente em conta as resistências ao cumprimento deles, a força instintual do Id e as dificuldades do ambiente real" ${ }^{57}$; donde se segue nosso mal-estar generalizado em relação àquilo que, em suas instâncias mais coletivas, a civilização busca mas jamais consegue curar - nossa agressividade. Tal como acontece com o Super-Eu Individual, as prescrições culturais incidem sobre nossa constituição psíquica de modo que desconsideram se é "humanamente possível cumpri-las" 58 . Assim, posta a inexequibilidade de "amar o próximo como à si mesmo", se nos damos conta de que as exigências individuais levam às formações neuróticas, devemos indagar se não seria justo apontarmos à possibilidade de que muitas comunidades se tornaram erráticas por influência de seus esforços culturais.

Recusando responder de maneira decisiva, Freud indica que a questão central para a humanidade é saber em que medida "sua evolução cultural poderá controlar as perturbações trazidas à vida em comum pelos instintos humanos de agressão e

\footnotetext{
${ }^{56}$ ENRIQUEZ, Da Horda ao Estado, p. 116

${ }^{57}$ FREUD, O Mal-Estar na Civilização, p. 118

${ }^{58}$ FREUD, O Mal-Estar na Civilização, p. 118
} 
autodestruição" "59. Para combater as forças aviltantes da pulsão de destruição, a cultura, filha e Eros e Ananke, se torna - progressiva e sistematicamente - serva da pulsão de morte e encontra em Thanatos um mentor soberano; razões estas que o levam a concluir seu texto com uma dúvida ainda mais radical:

Atualmente os seres humanos atingiram um tal controle das forças da natureza, que não lhes é difícil recorrerem a elas para se exterminarem até o último homem. Eles sabem disso; daí, em boa parte, o seu atual desassossego, sua infelicidade, seu medo. Cabe agora esperar que a outra das duas 'potências celestiais', o eterno Eros, empreenda um esforço para afirmar-se na luta contra o adversário igualmente imortal. Mas quem pode prever o sucesso e o desenlace? ${ }^{60}$

Ora, se de fato entendemos que o controle da humanidade sobre as forças da natureza é expressão da pulsão de destruição inibida na meta, então a centralização de nossa sociedade na promoção da exploração e transformação dos recursos naturais não só dá cada vez mais voz à esta pulsão, como tende a fazer com que ela fuja do controle de Eros e, através da necessidade (Ananke), se torne triunfante. Com o advento de novos dispositivos de controle, o triunfo da pulsão de destruição foi total, pois se em momento algum a influência da agressividade fora diminuída, tampouco as civilizações foram capazes de resolver os conflitos criados entre as exigências culturais e os mais distintos desejos individuais. Quando, em nome de um estado de bem-estar comum, promulga instituições e aumenta a infelicidade dos indivíduos, a cultura mostra-nos que não possui condições de fazer prevalecer seus mandamentos: "a civilização está minada pelo interior. Quanto mais ela se afirma, mais ela desaba"61.

A pulsão de morte não diz respeito somente à pulsão de destruição - contra a qual a civilização empenha-se continuamente -, mas é inerente à própria civilização, quando falamos de suas características mais repetitivas, homogeneizantes e cruéis. Assim, se afirmamos que os desígnios de Eros pressupõem um jogo de reciprocidade libidinal diante do desejo do outro, também não devemos deixar de ter em conta que quando nosso amor se dirige a unidades mais amplas, sem o saber, ele se rende ao fascínio de uma identificação narcísica para com os membros da comunidade.

Quando se dirige à cultura, o amor sucumbe "ao trabalho da pulsão de morte que se expressa pelo fascínio hipnótico dual do tipo sadomasoquista, pelo mimetismo e a submissão ao mesmo ideal" ${ }^{2}$. Desta feita, contra as possíveis manifestações das nossas tendências agressivas e em vista da civilização, os ideais do Super-Eu são de tal modo

\footnotetext{
${ }^{59}$ FREUD, O Mal-Estar na Civilização, p. 122

${ }^{60}$ FREUD, O Mal-Estar na Civilização, p. 122

${ }^{61}$ ENRIQUEZ, Da Horda ao Estado, p. 118

${ }^{62}$ ENRIQUEZ, Da Horda ao Estado, p. 119
} 
rígidos e cruéis que se tornam capazes de fomentar um sentimento coletivo e unificante de culpa, com o qual os indivíduos tendem a se identificar. Sendo o terreno fértil de Thanatos e da pulsão de morte, se é esta internalização jogada contra o Eu quem poderia explicar nossa resistência ${ }^{63}$ às curas impostas pela sociedade, então a civilização se edifica sobre aquilo que restou de nossa liberdade individual; o que ainda nos permite dizer que, em meio à luta entre as forças favoráveis à vida (Eros) e sua contraparte destrutiva (Thanatos), não há nada em nossa época capaz de nos garantir que a civilização não terminará numa catástrofe.

\section{3) Conclusão: contra a violência, novas formas de subjetivação}

A única saída frente à esta teleologia trágica decorrente do modo como a sociedade tratou estes impulsos destrutivos, somente pode ser encontrada via perspectiva clínica. Quando um indivíduo busca ajuda para lidar com algum sofrimento ou inquietação, é comum perceber em sua fala menções ao Outro, sendo este o responsável pelo surgimento das queixas de angústia. Por isso, o modo como lidamos com o real está diretamente ligado às demandas do Outro.

À medida em que o sujeito vai se implicando na análise, mais ele percebe a necessidade de desvencilhar-se da lógica fantasmática em que fora condicionado. Ao final da análise, ocorrerá aquilo que se denomina travessia da fantasia, e é aí onde muda sua posição, sendo chamado a responsabilizar-se por seus desejos ${ }^{64}$. No âmbito da sociedade, a conclusão assemelha-se a esta também, ou seja, diferente de uma ética em que visa afastar o real para longe - como queria Aristóteles -, a ética da psicanálise busca incluí-lo no interior da cultura, pois sabe que a negação, ao invés de afastar, só causará mais sintomas. E que chamamos de agressividade e mal-estar estão presentes em nossa própria condição.

O texto Por que a guerra? (1933) contém a troca de cartas entre Einstein e Freud, onde se questiona ora o motivo pelo qual o humano guerreia, ora o modo como, via psicanálise, poder-se-ia chegar numa alternativa para pacificar o mundo. Neste diálogo, Freud não contempla nenhuma ilusão ao afirmar que a possibilidade de encontrar uma resposta ao pacifismo seria fomentar condições para que os homens conseguissem sublimar a agressividade, desviando-a "num grau tal que não necessitem encontrar expressão na guerra”65. Para Freud, o ideal seria que a humanidade conseguisse a tal ponto

\footnotetext{
${ }^{63}$ A ânsia pode gerar sofrimento ou ainda a repetitividade do comportamento.

${ }^{64}$ Sobre a responsabilização pelo desejo, conferir um artigo que desenvolvi acerca desta ideia, qual seja, de que o sujeito somente consegue responsabilizar-se pelo seu desejo na medida em que afirma sua finitude, ou seja, sua falta. Cf. SANTOS; DALBOSCO, $A$ afirmação da finitude como possibilidade para a responsabilização do desejo: notas a partir de Heidegger e Lacan.

${ }^{65}$ FREUD, Por que a guerra?, p. 205
} 
subordinar sua vida pulsional "ao domínio da razão" ${ }^{66}$, devendo, portanto, recorrer à ciência como discurso mais eficaz para unificar os homens e impedir as barbáries. Concordamos parcialmente com esta tese, uma vez que ela nos mostra que a sublimação seria uma saída viável para os impulsos destrutivos; todavia, sabemos que os labores da razão, bem como das ciências principalmente, não são neutros. O discurso científico está relacionado com o desejo de poder, algo que está na origem de todas as manifestações de violência nas sociedades.

É por esta razão que pensamos ser a responsabilização pelo desejo, em sentido lacaniano, a possibilidade para uma sociedade menos hostil. Ora, se é verdade que "o inconsciente é estruturado como uma linguagem" ${ }^{67}$, então, quando crianças, recebemos do grande Outro os significantes que nos estruturam como sujeitos. Aprendemos a responder ao real à maneira dos ensinamentos advindos do Outro. Se, por exemplo, uma criança passa a entender que, para corrigir um erro ou resolver algum conflito, precisa recorrer à violência, muito provavelmente, quando se deparar com um evento semelhante, irá respondê-lo partindo dos significantes que, repetidas vezes, o grande Outro lhe impôs, e cujas agressões foram, aos poucos, internalizadas na conduta.

Seja com quem for, não são poucos os exemplos que podemos aqui listar, pois, voluntária ou involuntariamente, não raro repetimos no presente os traumas de outrora, sem que isto, necessariamente, cause prazer. Sabemos também que a reedição no presente de uma violência pregressa não justifica sua execução. De todo modo, podemos afirmar, conforme Paulo Freire, que a educação quando não tem o objetivo de ser libertadora, faz com que o sonho do oprimido seja ser opressor. Neste ponto, nossa hipótese encontra sustentação: a civilização só conseguirá lidar com sua própria catástrofe se se desvencilhar dos fantasmas que lhe assombram e, portanto, dos significantes que indicam o modo como responde ao real. Sejam quais forem as formas da violência, estas serão combatidas se conseguirmos pensar em novos modos de subjetivação, ou se quisermos, novas formas de gozo.

\section{Referências}

ARISTÓTELES. Ética a Nicômaco. 4. ed. São Paulo: Edipro, 2014.

DEIGH, J. La Ultima Teoría da la Civilización de Freud: cambio e implicaciones. In: JEROME, N (org.). Guia de Freud. Gran Bretaña: Cambridge University Press, 1996, p. 344369.

ENRIQUEZ, E. Da Horda ao Estado: Psicanálise do Vínculo Social. Rio de Janeiro: J. Zahar, 1990.

\footnotetext{
${ }^{66}$ FREUD, Por que a guerra?, p. 206

${ }^{67}$ LACAN, O seminário, livro 11: os quatro conceitos fundamentais da psicanálise, p. 27
} 
FREUD, S. O Mal-Estar na Civilização. In: FREUD, S. O Mal-Estar na Civilização, Novas Conferências Introdutórias à Psicanálise e Outros Textos. São Paulo: Companhia das Letras, 2010, vol. XVIII.

FREUD, S. Por que a guerra? In: FREUD, S. Edição Standard Brasileira das Obras Psicológicas Completas de Sigmund Freud. Rio de Janeiro: Imago, 1996.

GARCIA-ROZA, L. Introdução à metapsicologia freudiana. v. III. Rio de Janeiro: J. Zahar, 2014.

LACAN, J. O seminário, livro 7: a ética da psicanálise, 1959-1960. 2. ed. Rio de Janeiro: Zahar, 2008a.

LACAN, J. O seminário, livro 11: os quatro conceitos fundamentais da psicanálise. Rio de Janeiro: Zahar, 2008b.

LAPLANCHE, J.; PONTALIS, J. B. Vocabulário da psicanálise. São Paulo: Martins Fontes, 1986.

ROUDINESCO, E.; PLON, M. Dicionário de psicanálise. Rio de Janeiro: J. Zahar, 1998.

SANTOS, R.; DALBOSCO, J. A afirmação da finitude como possibilidade para a responsabilização do desejo: notas a partir de Heidegger e Lacan. Griot: Revista de Filosofia, v. 19, n. 1, p. 215-225, 28 fev. 2019. 